\title{
EDITORIAL
}

\section{GENDER AND ITS IMPLICATIONS IN ADULT LEARNING AND EDUCATION}

This issue of Studies in Adult Education and Learning explores gender and its implications in adult learning and education from different world perspectives. For Hearn and Collinson (2017, p. 27) the notion of gender is a "very complex set of embodied, institutionalized structures, practices and processes" and one of the most fundamental and powerful structuring social principles, which is constructed within very diverse contexts. Women and femininities, and men and masculinities, are seen as socially constructed, produced and reproduced, variable and changing across time and space, within societies, and through the life course. The notion of gender is local and global in nature but on the local level femininities and masculinities have to be understood within the context of culture, ethics, religion, space and language.

This thematic issue is concerned with continuing conversations through the investigation of the notions of gender. This special edition offers a rethinking of gender and its place in society. Equity, femininity and the norms of hegemonic masculinities are explored in this edition for the creation of a better, more socially aware reality.

Gender is examined through theories of representation as knowledge making by Darlene Clover, Nancy Taber and Kathy Sanford. Their paper looks at the mobilisation of pedagogical practices that enforce and re-enforce hegemonic masculinity and traditional femininity. They explore the museum and make use of the Feminist Museum Hack methodology to counter museum representations of power that perpetuate binaries of masculinity and femininity by taking up the 'battleground' of the museum to look deeper at gender-based images and language.

Hegemonic masculinity is also a theme in Annette Foley's paper where she makes a case that some feminist theorists on masculinity broadly agree that in some cases feminist positions of inequity and disadvantage can not only impact on the capability of women to achieve equal rights and citizenship but can render some groups of men as equally disadvantaged (Courtenay, 2000). In the Australian context Foley draws from a programme of research on men's sheds to make the case that some men's spaces such as men's sheds can and do contribute to the development of capabilities (Sen, 1997) which in turn develop better health and wellbeing outcomes for vulnerable men. 
Renata Šribar examines the representation of gender-related categories from de Beauvoir to Butler and beyond to ask which discourses related to gendered bodies are liberating and which gendered myths, phrases and arguments are oppressive. The paper discusses the taxonomies of European Union institutions regarding official terminologies and conceptual gender/sex ambivalences in knowledge discrimination in the EU. The paper concludes that there is a lack of gender-related research in adult education which is worrisome considering one of the principles in the field is to foster critical thinking to help combat discrimination.

Anitra Goriss-Hunter, Adele Echter, Taiwo Oseni and Sally Firmin look at 'undoing' gender in the context of Science, Technology, Engineering, Mathematics and Medicine (STEMM) education at an Australian university. The paper examines the issue of women's under-representation in science education and draws on gender theories that identify education settings such as universities as strategic sites of influence, places where open debates and gender relations are likely to happen. The paper draws from a self-study methodology where women from the Science, Engineering and Information Technology Women's Group at Federation University Australia attempt to move beyond the restrictions of the traditional gender narrative to encourage more women to participate in STEMM.

The two books selected to be reviewed for this special edition further direct our attention to the complex nature of the question of gender.

Science (without) Youth: Gendering Early Academic Careers in Slovenia (edited by Ana Hofman). This book is a result of the GARCIA project that targets gender inequalities in academia. The edited book provides an insight into the complex nature of gender regimes in Slovenian academic circles.

Anti-Gender Campaigns in Europe: Mobilizing Against Equality (edited by Roman Kuhar and David Patterson). This book presents an analysis of the anti-gender movement campaigns in Europe and examines the appropriation of language used against the rights of women, the LGBTIQ community and numerous social others such as refugees and migrants. The book critically explores these campaigns against equality.

The university setting is also taken up by Monika Govekar-Okoliš and Renata Kranjčec's non-thematic paper where they discuss the role of mentors in the formal mentoring of college students in the Faculty of Arts at the University of Ljubljana. The findings shine light on to the correlation between familiarity of tasks and how they are performed and realised. 


\section{REFERENCES}

Courtenay, W. (2000). Constructions of masculinity and their influence on men's well-being: A theory of gender and health. Social Science and Medicine, 50, 1385-1401.

Hearn, J. and Collinson, D. (2017). Men, masculinities and gendered organizations. In R. Aldag and S. Nkomo (ed.), Oxford Research Encyclopedia of Business and Management (p. 35). New York: Oxford University Press.

Sen, A. (1997). Editorial: Human capital and human capability. World Development, 25(12), 1959-61. 